\title{
Aboriginal Policing in Rural Canada: Establishing a Research Agenda
}

Savvas Lithopoulos

Senior Research Officer

Aboriginal Policing Directorate

Public Safety Canada

Ottawa, Ontario, Canada

Phone: (613) 998-7627

Email: savvas.lithopoulos@ps-sp.gc.ca

Rick Ruddell

Law Foundation of Saskatchewan Chair in Police Studies

Department of Justice Studies

University of Regina

3737 Wascana Parkway

Regina, Saskatchewan, Canada, S4S 0A2

Contact author - Rick Ruddell: rick.ruddell@ uregina.ca; 0013063378541

\begin{abstract}
Canada's First Nations Policing Program (FNPP) provides the funding and programmatic structure for policing 535 rural Aboriginal communities. After two decades and almost three billion (CA) dollars in expenditures, however, there has been comparatively little scholarly assessment of the strengths and weaknesses of this approach to policing. This study highlights the current state of the FNPP and we find that most government funded research has focused upon the administrative goals of the FNPP while relatively little government or scholarly attention has been paid to program outcomes. We identified three broad needs for Aboriginal policing research in Canada, including; (a) developing a research based inventory of best practices in rural and Aboriginal policing; (b) examining the efficacy of plural policing; and (c) how the study of Aboriginal policing can inform organizational theory. Each of these issues has implications for the development of research, practice, policy, and theory, and ultimately, ensuring just and fair outcomes concerning public safety for Canada's Aboriginal peoples.
\end{abstract}

\section{Keywords: Aboriginal policing, First Nations Policing Program (FNPP), Rural policing}




\section{Introduction}

With the establishment of the First Nations Policing Program (hereafter: FNPP or the Program) in 1992, Canada became the only country that had developed a comprehensive national policing strategy for its Aboriginal peoples. ${ }^{1}$ The FNPP introduced a number of innovative features, including its tripartite approach, partnerships between the federal and provincial governments and First Nations, which has not been duplicated in other nations (Lithopoulos, 2007). Moreover, its mix of federal and provincial funding and support enabled First Nations to work toward self-determination, which is an important consideration given the paternalism and discrimination that shaped Aboriginal people's relationships with all levels of government throughout Canadian history (Adjin-Tettey, 2007). Two decades after the implementation of the FNPP, and over $\$ 2.74$ billion in federal and provincial funding (see Appendix A) there has been little academic research on the Program. This study highlights the current status of the FNPP and proposes a number of starting points for empirical inquiry so that investigators can more accurately evaluate the strengths and weaknesses of this approach to rural and remote policing.

According to Murphy (1999), Canadian government support for policing research eroded due to a bureaucratic rationalization from the late 1980s to the early 1990s. Ironically, this lack of support for police research is contrasted against the expanding government funding for policing research in other countries such as the United Kingdom, United States, and Australia. Murphy (1999, p. 210) concluded that, "Canadian governments and their police forces appear to be in a curious state of performance indifference, which suggests a disturbingly indifferent approach to the governance of policing." While the volume of police research has increased in recent years, Robertson (2012, p. 360) noted that "there is often a divide between academics and police practitioners." As a result, the conservative nature of Canadian policing may reduce participation in research partnerships, which in turn can reduce experimentation and innovation.

Within this context, Aboriginal policing is one of the most under-researched aspects of Canadian law enforcement. Apart from government technical reports, or reports commissioned by the federal government as a result of major inquiries, there is a dearth of academic literature on Aboriginal policing and almost a total absence of a critical overview of the FNPP since its inception in $1992 .^{2}$ This lack of scholarly interest is rather surprising considering that Canada's Aboriginal peoples have a high involvement in crimes reported to the police and are disproportionately incarcerated. For example, in 2004, the total on-reserve crime rate was about three times higher than rates in the rest of Canada, and rates of violence were up to eight times greater (Brzozowski, Taylor-Butts, \& Johnson, 2006, p. 1). As a result, the likelihood of victimization among Aboriginal peoples was much larger than other Canadians (Perreault \& Brennan, 2010). Last, although representing about 3.8\% of the national population, Canada's Aboriginal peoples comprised $27 \%$ of admissions to provincial sentenced custody and $20 \%$ to federal custody (Dauvergne, 2012, p. 11). Altogether, a growing number of Aboriginal persons, living both on- and off-reserve, are involved in Canadian justice systems as offenders or victims. 
In addition to increased involvement in crime, the Aboriginal population is growing. In the 2006 Census, for example, almost 1.2 million people identified themselves as Aboriginal, representing an increase of $45 \%$ over the 1996 figure of 799,000, which compares to a growth rate of 8 percent for non-Aboriginal residents (Statistics Canada, 2008, 6). In addition, it is a youthful population, and Statistics Canada $(2008,6)$ reported that, "Almost half $(48 \%)$ of the Aboriginal population consists of children and youth aged twenty-four years and under, compared with 31 percent of the non-Aboriginal population." These demographic characteristics have implications for Canada's criminal justice systems, as members of this age group tend to be involved in crime at higher rates than their older counterparts.

The inattention to issues of rural policing in Canada is also consistent with practices in other nations, where criminal justice research often has a "big city" bias. This attention on practices and policies in urban areas occurs for a number of reasons, including the fact that larger justice systems often have the funding to support empirical studies, and research universities are often located in cities and it is more convenient for academics to study what occurs locally. Furthermore, there may be a perception that interventions in smaller jurisdictions are less interesting or sophisticated than innovations developed in urban areas. Regardless of the reasons, however, this inattention represents a significant limitation in our understanding because rural and Aboriginal policing is different than conventional policing, but few recent studies have described those differences.

The aim of this commentary is to add to the discourse on Canadian law enforcement by providing an overview of Aboriginal policing and the FNPP in particular. In addition to defining the current status of the FNPP, we provide a reference point for future policy oriented and theoretically related research in this unique and under researched form of policing. To this end, this examination addresses this subject in the following way: (1) the contextual background is defined through an overview of Aboriginal policing in Canada and a short description of the development of the FNPP; (2) an overview of current research on the Program is presented; and (3) a future research agenda is advanced based upon our analysis of the strengths and weaknesses of the FNPP.

\section{An Overview of Aboriginal Policing in Canada}

Historically, the Canadian federal government, through the Royal Canadian Mounted Police (RCMP) and its predecessor, the Northwest Mounted Police, enforced the laws on reservations and kept the peace between Aboriginal peoples and European immigrants. Their aim was to encourage settlement and economic development of the Canadian western frontier by ensuring that Aboriginal peoples remained on their reservations (Lithopoulos, 1986) ${ }^{3}$. While the history of relationships between the police and Aboriginal peoples in Canada is less violent and oppressive than what occurred in either Australia or the United States prior to the $20^{\text {th }}$ century (Nettelbeck \& Smandych, 2010), Canadian governments used the RCMP to enforce social policies, such as the removal of Aboriginal youth from their communities and placement in 
residential schools, that today are considered discriminatory, destructive, and paternalistic (Christmas, 2012). As a result of those historical activities the members of the RCMP are not always trusted by Aboriginal peoples (LeBeuf, 2011).

Until the 1960s, the prevailing view was that the federal government was fully responsible for all aspects of Indian affairs and had sole jurisdiction for all Indian reserves. This perspective began to lose legitimacy in the 1960s and 1970s as a result of several Supreme Court decisions that increased the provincial jurisdiction over Aboriginal peoples both on- and off-reserve. One outcome of these changes was that the RCMP began to withdraw from policing reserves in the provinces of Ontario and Quebec as the federal role evolved from providing direct police service delivery in favour of financial support for on-reserve policing (Department of Indian Affairs and Northern Development [DIAND] 1990). The withdrawal of the RCMP from reserve policing in Ontario and Quebec resulted in these rural and often isolated communities being the most chronically under-policed locations in Canada. It contributed to a pattern of high rates of disorder, crime, and personal victimization that persists to this day.

By the late 1970s, a number of different approaches to Aboriginal policing were emerging throughout the nation. These included the introduction of Indian Special Constable Programs within federal and provincial police services that deployed more Aboriginal officers on reserves ${ }^{4}$. Band constables, first introduced in 1965, were non-sworn officials who supported the activities of the police. These constables were empowered to enforce bylaws and civil matters pursuant to the Indian Act (Department of Justice Canada, 1985). Despite the fact that they received little training and were not authorized to carry firearms, they played an important role by providing informal social control as well as engaging in crime prevention activities, and some Bands still employ these officials.

During this era, several self-administered police services were founded, such as Manitoba's Dakota Ojibway Police Service and Quebec's James Bay Tribal Council, which were both established in 1978 (DIAND,1990). The first tripartite agreement (the Ontario Indian Constable Program) was signed in 1981, with officials from the federal, Ontario and First Nations governments participating (DIAND, 1982). By 1982, about 500 Aboriginal officers and 130 band constables were policing Aboriginal communities (Clairmont, 2006). Altogether, both the participation and responsibility level of Aboriginal peoples in the delivery of law enforcement were increasing but without any clear direction, formalized structure, or consistent funding arrangements.

In the 1980s the federal government engaged in a comprehensive review of Aboriginal policing (DIAND, 1983; 1990). The rationale for this review was concern over the makeshift policing arrangements that were emerging throughout the nation. One of the key findings of this research was that Aboriginal policing services were being delivered in an inequitable manner compared to non-Aboriginal communities (DIAND, 1983). In many cases, these fledgling 
policing services were ineffective, inefficient and unresponsive to the needs of the Aboriginal communities they served. Some Aboriginal policing services were found to be unprofessional, lacked appropriate accountability mechanisms and did not provide Aboriginal peoples with a say in the type or level of policing services provided (Cardinal, 1998). These reviews also concluded that personal security for reserve residents was lower than for other Canadians (DIAND, 1983; Solicitor General of Canada, 1992b).

In addition to identifying the limitations in policing First Nations, the federal review discovered that most of the policing services to Aboriginal communities were delivered by nonAboriginal police officers (DIAND, 1983). Consultations with stakeholders from Aboriginal communities revealed specific problems with these policing arrangements, and they included:

a) Chronic under-policing reflected by a lack of regular police presence and a poor response time to incidents;

b) A lack of preventive patrol and crime prevention programs in such critical areas as family violence and substance abuse;

c) A lack of understanding of, and sensitivity to, Aboriginal culture by nonAboriginal police officers;

d) Absence of a clear federal policy, leadership, and professional standards across Canada;

e) Confusion over jurisdiction and responsibilities with and between governments;

f) Absence of provincial legislation providing for the establishment and regulation of Aboriginal police services; and

g) Insufficient and inequitable funding of Aboriginal policing.

At about the same time as these federal government reports were released, a number of provincial inquires were also taking place. From 1967 to 1990, a total of 25 federal and provincial reports were published that addressed the involvement of Aboriginal persons with criminal justice systems (Alberta Government, 1991). Of these reports, 22 offered recommendations and the Alberta Government (1991, 4-13) summarized these into a number of key themes, including: the expansion of policing services to First Nations, the need to upgrade the band constable program, increased community involvement in the policing process, higher levels of cross-cultural training, and that more Aboriginal persons be hired to work in justice systems. The growing concern about Aboriginal persons and their involvement with justice systems, and especially how their communities were being policed, could not easily be dismissed, and there were growing political demands to make meaningful changes. 


\section{The Development of the First Nations Policing Program}

The federal and provincial reports and reviews of Aboriginal people's involvement in criminal justice systems combined with a growing Aboriginal political militancy led to the development of the First Nations Policing Policy in $1992^{5}$. The FNPP's primary goal was to provide First Nations and Inuit communities with professional and culturally appropriate policing $^{6}$ and replace the existing policing arrangements, such as the band constable program and RCMP Indian Special Constables with Aboriginal officers (Solicitor General of Canada, 1992a; $1992 b ; 1996)^{7}$. Inherent in the FNPP was the notion that Aboriginal officers would be more effective in policing on-reserve populations than non-Aboriginal officers.

A cornerstone of the FNPP is that the Canadian government has provided funding to entice provincial governments, which have primary jurisdiction over policing, to negotiate and implement tripartite agreements involving the federal, provincial, and First Nations governments. This was accomplished through a cost sharing formula where the federal government incurs $52 \%$ of the costs of these policing agreements, and provincial governments pay the remainder. The provinces have generally reacted favourably to the FNPP as it respected their constitutional responsibilities for policing. In addition, the FNPP provided a very strong enticement for Aboriginal participation into the FNPP as they had no obligation to contribute to the direct costs of establishing and maintaining their self-administered police services.

Table 1 illustrates, that as of November 1, 2010, the Program consisted of 167 tripartite policing agreements funding 1,243 officer positions and serving 398 Aboriginal communities. In addition, the Program still provides funding for 223 legacy (pre-FNPP policing) positions including 78 RCMP Aboriginal Community Constable Program officers (10\% of the total funded positions) and an estimated 145 band constables (5\% of the total funded positions). While the total number of officers policing First Nations represented a small proportion of the 69,299 sworn officers working throughout Canada in 2010 (Burczycka, 2010, 5) their roles are critical in the communities that they serve.

The two most common policing arrangements under the FNPP are the 38 First Nations Administered (FNA) police service agreements and 117 RCMP Community Tripartite Agreements (CTA). In addition, there are three Municipal Quadripartite policing agreements. These arrangements accounted for $85 \%$ of all funded officer positions, with the remaining positions staffed by members of the Ontario and Quebec (Sûreté du Québec) provincial police services. An FNA is a tripartite policing agreement between the federal government, a participating province, and a First Nation or several First Nations (e.g., a tribal council that represents a group of First Nations). The First Nation(s) develops, manages, and administers their police services pursuant to provincial policing legislation. Table 1 shows that there were 823 FNA officers - representing 56\% of all funded officer positions under the Programworking within these self-administered services on November 1, 2010. 
Table 1: First Nations Policing Program, November 1, 2010

\begin{tabular}{|c|c|c|c|c|c|}
\hline $\begin{array}{l}\text { FNPP Policing } \\
\text { Agreement }\end{array}$ & $\begin{array}{l}\text { Number of } \\
\text { agreements }\end{array}$ & $\begin{array}{l}\text { Population } \\
\text { covered }\end{array}$ & $\begin{array}{c}\text { Number of } \\
\text { communities } \\
\text { policed }\end{array}$ & Officers & $\begin{array}{c}\text { Percent } \\
\text { of total } \\
\text { officers }\end{array}$ \\
\hline $\begin{array}{l}\text { First Nations } \\
\text { Administered (FNA) }\end{array}$ & 38 & 159,517 & 175 & 823 & $56 \%$ \\
\hline $\begin{array}{l}\text { RCMP Community } \\
\text { Tripartite Agreement } \\
\text { (CTA) }\end{array}$ & 117 & 156,690 & 199 & 383 & $26 \%$ \\
\hline $\begin{array}{l}\text { RCMP Provincial } \\
\text { Framework Agreement }\end{array}$ & 9 & 12,958 & 21 & 26 & $2 \%$ \\
\hline $\begin{array}{l}\text { Municipal Quadripartite } \\
\text { Agreements }\end{array}$ & 3 & 1,757 & 3 & 11 & $1 \%$ \\
\hline Total FNPP & 167 & 330,922 & 398 & 1,243 & $85 \%$ \\
\hline \multicolumn{6}{|l|}{ Legacy Programs } \\
\hline $\begin{array}{l}\text { Band Constable } \\
\text { Program (BCP) }\end{array}$ & N/A & 69,726 & 49 & $\begin{array}{c}145 \\
\text { (estimate) }\end{array}$ & $10 \%$ \\
\hline $\begin{array}{l}\text { RCMP Aboriginal } \\
\text { Community Constable } \\
\text { Program }\end{array}$ & $\begin{array}{c}56 \\
\text { detachments }\end{array}$ & 97,612 & 88 & 78 & $5 \%$ \\
\hline $\begin{array}{l}\text { Total Legacy } \\
\text { Programs }\end{array}$ & N/A & 167,338 & 137 & 223 & $15 \%$ \\
\hline Grand Total & 167 & 498,260 & 535 & 1,466 & $100 \%$ \\
\hline
\end{tabular}

An RCMP CTA, by contrast, is a tripartite agreement negotiated between Canada, a participating province, and a First Nations group or tribal council. Under these arrangements, the RCMP attempts to fill these on-reserve policing positions with Aboriginal officers. On November 1, 2010, there were 383 CTA officers representing 26\% of all FNPP funded officers. In order to support the RCMP CTAs, there are nine bilateral Provincial Framework Agreements between the federal and provincial governments. These provide the administrative and financial structures for the individual RCMP CTAs and must be in place prior to negotiating these agreements. There were 26 officers ( $2 \%$ of the total funded positions) providing liaison and 
support for the CTA detachments under these agreements on November 1, 2010 (Public Safety Canada, 2010b).

Although rare, several municipal police services have entered into arrangements with the federal, provincial, and First Nations to provide policing services to an Aboriginal community that is adjacent to a city. On November 1, 2010, only 11 officers (1\% of the total funded positions) provided policing services to First Nations under these municipal quadripartite agreements.

Regardless of the form that Aboriginal policing takes, each First Nation has oversight on the delivery of policing services through boards that monitor the activities of the police. First Nations that create a self-administered police service must also establish an independent Police Governance Board (often called a police management board or a police commission) to represent the policing concerns and interests of the community. With the CTA model, the First Nations communities are expected to establish and maintain a Community Consultative Group. This group provides a forum for liaison and discussion between the band, the police, and the community (Public Safety Canada, 2009; 2010a).

Altogether, the FNPP provides an innovative approach to providing policing services to Aboriginal communities that has not been duplicated in other nations with high proportions of indigenous peoples (Lithopoulos, 2007). In the following pages we highlight the current state of knowledge about Aboriginal policing in Canada and follow that section with three broad research questions that have implications for the development of practice, policy and theory.

\section{Aboriginal Policing in Canada: Current Research and Unanswered Questions}

Two decades after the introduction of the FNPP we have very little knowledge about the effectiveness of the Program and have yet to develop an inventory of best or evidence-based practices that would enable practitioners to deliver more effective services. In addition, there has been comparatively little theoretical development that helps us understand the role of Aboriginal policing in terms of both organizational theory and the place of Aboriginal policing within Canadian law enforcement and rural policing. Having described the context and current state of the FNPP, the key issue that will shape the future of Aboriginal policing research in Canada is the focus on the administrative goals of the FNPP and relative inattention to program outcomes. This issue has implications for the development of practice, policy, and theory of Aboriginal policing in Canada.

\section{Defining FNPP Success: Administrative Goals or Program Outcomes?}

Writing about police executives, Goldstein (1979, p. 236-237) observed that, "all bureaucracies risk becoming so preoccupied with running their organizations and getting so involved in their methods of operating that they lose sight of the primary purposes for which they 
were created." One of the challenges of the FNPP is that its focus has been on bureaucratic indicators of success, such as the total number of tripartite agreements, the percentage of Aboriginal people employed as police officers, as well as the proportion of First Nations communities and populations covered under the Program. In other words, the growth of the Program has been equated with success. A criticism of this focus on bureaucratic goals, however, is that it has shed very little light about the actual effectiveness of Aboriginal policing (see Public Safety Canada, 2010a) and whether these services are delivered in a manner that is just, fair, effective, and respectful to the needs of the communities being policed.

The lack of systematic and ongoing research on Program effectiveness has led to an inability to gauge Aboriginal people's levels of trust in Aboriginal policing over time. This is unfortunate as there is a growing body of research and scholarly commentary that has drawn our attention to the relationships between legitimacy and law abiding behavior and that "public trust in policing is needed partly because this may result in public cooperation with justice, but more importantly because public trust in justice builds institutional legitimacy and thus public compliance with the law, and commitment to, the rule of law" (Hough, Jackson, Bradford, Myhill \& Quinton, 2010, p. 203). This procedural justice thesis suggests that if the criminaljustice system is not regarded as fair, people are significantly less likely to obey the law or cooperate with the police (see also Tyler, 2006). The historical mistrust between the Aboriginal peoples and the police may be a factor that contributes to high rates of crime in Aboriginal communities. In a provocative statement, Unnever and Gabbidon (2011) posited that the experience of long-term racism, pejorative stereotypes, marginalization, as well as disproportionate treatment by justice systems plays a role in increased offending.

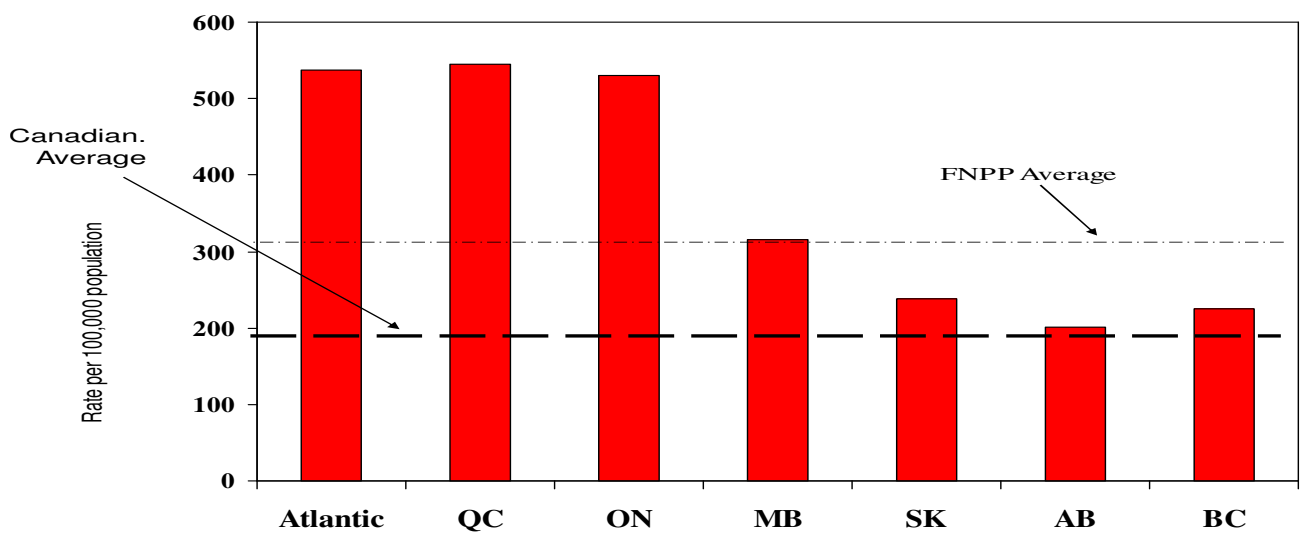

Note: Atlantic Canada includes the provinces of Newfoundland, New Brunswick, Nova Scotia, and Prince Edward Island; $\mathrm{QC}=$ Quebec; $\mathrm{ON}=$ Ontario; $\mathrm{MB}=$ Manitoba; $\mathrm{SK}=$ Saskatchewan; $\mathrm{AB}=$ Alberta, and $\mathrm{BC}=$ British Columbia. Source: Public Safety Canada unpublished data

Figure 1: Rate of FNPP Police Officers per 100,000 Population, by Province, 2009/10 
A recent Public Safety Canada (2010a, p. 12-19) evaluation of the FNPP highlighted three areas where Aboriginal policing ought to be examined, including the issue of cultural appropriateness, the responsiveness of police services on First Nations, and innovative service delivery options. However, the report only specifically addressed the subject of responsiveness using results from a survey conducted in 2010. The following paragraphs provide an overview of these issues.

In terms of specific dimensions of police performance an Ekos Research Associates (2005, 45) study reported that 43 percent of on-reserve respondents felt that the police did a good job of keeping citizens safe, 36 percent said that the police did a good job of enforcing the law, and only 32 percent maintained that police responded quickly enough when called. There was, however, considerable inter-provincial variation within these results, and Alberta First Nations communities, which have the lowest number of FNPP police officers per 100,000 residents in the population (see Figure 1) expressed the least favourable attitudes toward police services. These self-reported data on four dimensions of police performance were contrasted against police staffing levels ${ }^{8}$. Respondents from the provinces with the highest ratio of officers per 100,000 residents in the population (e.g., the four Atlantic provinces, Quebec, and Ontario) expressed higher levels of satisfaction with police performance than on-reserve residents in the four western provinces with the lowest ratio of officers to residents (British Columbia, Saskatchewan, Manitoba, and Alberta), and t-tests showed that these differences were statistically significant at the $p \leq .05$ level. In other words, the on-reserve respondents' opinion in the four western provinces is a reflection of the chronic under-policing in their communities. Such results are not surprising considering that the percentage difference in the number of police officers per 100,000 residents in the population between the provinces of Quebec and Alberta is $171 \%$.

Table 2: Number of FNPP Police per 100,000 First Nations Residents

\begin{tabular}{|lc|}
\hline Jurisdiction/Province & Number of FNPP police \\
\hline 1. Quebec & 545 \\
2. Atlantic Canada & 537 \\
3. Ontario & 530 \\
4. British Columbia & 225 \\
5. Saskatchewan & 238 \\
6. Manitoba & 316 \\
7. Alberta & 201 \\
\hline
\end{tabular}

Note: Atlantic Canada includes the provinces of Newfoundland, New Brunswick, Nova Scotia, and Prince Edward Island; Source: Public Safety Canada (Unpublished data) 
The Public Safety Canada (2010a) evaluation used data from surveys conducted in early 2010 and the results are presented in Table 3. This table shows the outcomes of surveys received from community stakeholders (e.g., Chiefs, Band council members, and members of police advisory boards) and their satisfaction with 12 dimensions of policing services (indicated by the respondent's agreement with statements that policing services were "good" or greater). The comparison showed that the CTA police services are perceived to have higher levels of professionalism, are more effective at criminal code and provincial statute enforcement, are independent from inappropriate (e.g., political) influences, and are more effective working with other police services. FNAs, by contrast, were perceived to do a better job of keeping citizens safe, protecting property, being visible, and providing a prompt response to calls for service. The differences between the two types of organizations in crime prevention or enforcing Band bylaws were, however, non-existent.

\section{Table 3: Percentage of First Nations Community Stakeholders Agreeing that Policing Services were "Good" or Higher}

\begin{tabular}{lcc} 
Attributes & $\begin{array}{c}\text { CTA (RCMP } \\
\text { Contract Policing) }\end{array}$ & $\begin{array}{c}\text { FNA - First } \\
\text { Nations Policing }\end{array}$ \\
\hline High level of professionalism & $93 \%$ & $75 \%$ \\
Enforcing criminal code & $87 \%$ & $75 \%$ \\
Working with other police services & $86 \%$ & $67 \%$ \\
Enforcing provincial statutes & $72 \%$ & $58 \%$ \\
Independent from inappropriate & $72 \%$ & $50 \%$ \\
$\quad$ influence & & \\
Keeping citizens safe & $64 \%$ & $67 \%$ \\
Protecting property & $50 \%$ & $67 \%$ \\
Providing crime prevention $\quad$ information & $44 \%$ & $50 \%$ \\
Being visible & & \\
Preventing crime & $39 \%$ & $50 \%$ \\
Enforcing band bylaws & $33 \%$ & $33 \%$ \\
Prompt response to calls for service. & $31 \%$ & $33 \%$ \\
\hline
\end{tabular}

Source: Public Safety Canada (2010a, 14)

Dissatisfaction with police services is often associated with the performance of these agencies. In addition, administrative competence may be a valid outcome measure as the state of some FNAs had historically been chaotic: personnel were disorganized, operations run inefficiently or were poorly managed, some agencies were ripe with political interference, and lacked accountability (Cardinal, 1998; Clairmont \& Murphy 2000; Murphy \& Clairmont, 1996; Navigant Consulting, 2008). An evaluation of the FNPP in Ontario found that 40 percent of FNA officers had not successfully completed their training at the Ontario Police College (Smith Associates et. al., 1997). Many of those failed recruits had not completed their secondary schooling or equivalent educational requirements. As a result, deploying these officers in the 
early years of the Program may have contributed to a reduction in agency legitimacy and less than professional services. Given these results, the management and operation of FNAs requires some current investigation to determine whether more officers today are successful in their training and perhaps more importantly, their operational effectiveness.

RCMP CTAs, on the other hand, generally suffer from inadequate staffing levels to deal with the operational demands of high need communities and the requirement to provide policing outside the First Nations to which they are assigned (see Alderson-Gill \& Associates, 2006; Office of the Auditor General of Canada, 2005; Prairie Research Associates, 2006). The Auditor General of Canada's (2005) examination of RCMP contract policing, for example, found that the RCMP failed to live up to their obligations to First Nations. According to the Auditor General this may be a result of role confusion, misunderstanding the goals of the FNPP and a conflict of interest in the additional role of the RCMP as a provincial police service (e.g., providing policing to off-reserve residents in rural areas).

It should be noted, however, that all of the studies mentioned above found that community residents were generally satisfied with the overall service they received from the RCMP officers once they responded to calls for service. Subsequent research revealed that Aboriginal community members were satisfied with the quality of police services they received from the RCMP, but have concerns over lengthy response times and officer visibility, especially in communities that are relatively distant from RCMP detachments (Alderson-Gill \& Associates, 2006).

Another issue associated with program outcomes is providing culturally relevant policing, which played a key role in the inception and development of the FNPP. Alderson-Gill \& Associates (2008) argued that it plays a critical role on how officers deal with disorder and crime in Aboriginal communities. Earlier we defined culturally relevant or appropriate policing as services delivered by Aboriginal officers. The Public Safety Canada (2010a, p. 12) evaluation did not define cultural relevance, and instead stated that, "communities funded pursuant to an FNPP agreement are in the best position to do so."

While there is an explicit assumption in the principles of the FNPP concerning the employment of officers with a similar ethnocultural background, and who have linguistic abilities that are similar to the peoples they police are more likely to be effective, as well as being positive role models for youth, evaluations have not been conducted to determine whether this is truly the case (Ruddell \& Lithopoulos, 2011). According to the National Research Council's (2004) review of policing research in the United States and the Alderson-Gill \& Associates (2008) study of FNPP officers in Canada, an officer's ethnocultural, linguistic, or gender background is not a relevant factor on their job performance, job satisfaction, or personality. In addition, there is considerable diversity within First Nations populations due to the presence of sixty different Aboriginal languages in Canada and different cultural values, 
traditions, and religious beliefs within and between these groups (Statistics Canada, 2008). Even if officers are Aboriginal, they may not have the same linguistic abilities or cultural background as the Aboriginal peoples they police.

The results of three surveys of officers policing Aboriginal communities suggest that the Program has not increased the proportion of Aboriginal officers. Murphy and Clairmont (1996) reported that 90 percent of the officers were Aboriginal. A follow-up study of officers conducted by Alderson-Gill \& Associates (2008) reported that $69 \%$ of the respondents were Aboriginal, while the most recent Public Safety Canada (2010b) survey of officers found that 63.9 percent self-declared as being Aboriginal. The change was most marked in the RCMP, where 94 percent of the officers were Aboriginal in 1996, 59 percent in 2007, and 50.7 percent in 2010 (Public Safety Canada, 2010b). This trend is also apparent in the FNA police services as $86 \%$ of officers were Aboriginal in 1996 versus 78 percent in 2007, and 73.3\% in 2010. Some caution must be made in interpreting these results, as they are based on self-reported information, but as the sample size in these studies was greater than one-third of all Aboriginal officers, these results are likely to be fairly representative. Aboriginal policing with a decreasing number of Aboriginal officers may be perceived by policymakers as a limitation of the FNPP, but may be a moot point for rural and isolated Aboriginal communities that are under-policed. For these communities, any professional officer is better than no officer as recruiting and retaining Aboriginal officers continues to be a challenging task (Jain, Singh, \& Agocs, 2000).

The focus on bureaucratic indicators of success for Aboriginal policing is not surprising as many governments tend to be more interested in shaping appearances rather than demonstrating policy and program effectiveness through evidence-based evaluation. The latter, takes a great deal of time and effort to accomplish, while the former, satisfies the "political need for instant accountability" (National Research Council, 2004, p. 35).

Given this context, in the following section, a future research agenda is advanced for Aboriginal policing based upon our analysis of the strengths and weaknesses of the FNPP. Specifically, we propose that there is a need to: (1) develop an inventory of best practices in rural and Aboriginal policing based on the principles of evidence-based policing; (2) examine the efficacy of plural policing in rural Aboriginal communities; and (3) conduct research on the life course of Aboriginal police services.

\section{A Research Agenda for the FNPP}

\section{(1) Developing an Inventory of Best Practices in Rural and Aboriginal Policing}

There has been increasing interest in the social and health sciences about the delivery of services based on what the empirical research demonstrates as effective, or what is also called evidence-based practice. Sherman (1998) was one of the first scholars to draw attention to the evidence-based policing approach. There is strong evidence, for example, that focused tactics 
and strategies of the police concerning locations, offenders, victims, and time, have a positive effect in preventing and lowering crime and disorder in urban areas (Lum, Koper \& Telep, 2011; National Research Council, 2004; Sherman, 2011). There is a lack of evidence, however, whether these strategies are equally effective in rural communities.

Considering the very high crime and victimization rates in Canada's Aboriginal communities, developing an inventory of best practices in rural and Aboriginal policing should be a priority. Police scholars and practitioners, however, have not established such an inventory, and this makes it more difficult for newly founded Aboriginal police services to overcome barriers that might be common to all of these agencies. To a large extent, these best practices may be shaped by the size of the agency, whether the communities being policed are urban or rural, as well as the forms of crime that they must confront, ranging from minor social disorder in some Aboriginal communities to gangs and organized crime in others.

Clairmont (2009, p. 11) described four types of self-administered Aboriginal police organizations in Canada, (a) the Full-service town model, (b) the Niche model, (c) the Regional model, and (d) the Micro transitional model, and these classifications might serve as a useful starting point for the establishment of inventories of best practices, as each type of organization may require a slightly different administrative approach.

Several full-service town departments such as Akwesasne and Six Nations were established prior to the enactment of the FNPP, and serve relatively large communities (the Six Nations council, for instance, has the largest on-reserve population in Canada, with almost 12,000 residents). Clairmont (2006, p. 63) defined niche departments, by contrast, as emerging from First Nations "insist[ing] on a police service tailored to their own specific values and needs." The Regional model, involves growth and is exemplified by Ontario's Nishnawbe Aski Police Services (NAPS) that employed 175 officers and policed 35 communities in 2012, and is the second largest Aboriginal-operated police service in North America. Last, the Micro transitional departments are small stand-alone agencies. Clairmont (2006) observed that these micro-sized agencies - usually deploying fewer than ten officers - are more apt to fail due to their standalone character, which is consistent with U.S. research (King, 2009b).

The size and inter-connectedness of these FNAs shape the types of services that they will deliver, and they also play a significant role in the needs of these police organizations. The fact that police resources are stretched thin in many First Nations results in incident-driven and reactive policing (Clairmont, 2006). Moving beyond that approach is critical for crime prevention and reducing victimization.

Inventories of best practices are intended to increase organizational effectiveness and reduce the likelihood of unanticipated outcomes and organizational crisis. While the existence of such inventories is no guarantee that agency leaders will take full advantage of them, they would 
also serve as a solid foundation for future research, staff development and training, as well as theoretical development in Aboriginal policing.

\section{(2) Examining the Efficacy of Plural Policing}

The notion that government funded police services are solely responsible for ensuring public safety has been eroding in recent years (Bayley \& Nixon, 2010; Merritt \& Dingwall, 2010; Rogers \& Gravelle, 2012). Instead, there is a growing realization that there is a patchwork of public, private, and community agencies and individuals that provide formal and informal social control in rural and urban settings. Loader (2000) defined six different types of social control that ranged from the government-sponsored or public police to the unregulated and unsanctioned activities of civilians. Since 1965 there have been an increasing number of nonsworn officials who provide security as well as informal social control in Aboriginal communities. These officials can take the form of private security officers who are hired by the Band to safeguard infrastructure and resources, or individuals who are hired in crime prevention roles. These officials, with varying degrees of formal authority, augment the activities of the sworn police officers.

Among the first non-sworn officials to engage in crime prevention activities on First Nations were the band constables, and there are currently an estimated 145 of them funded through Public Safety Canada. These officials provide an important service in communities where no RCMP detachment exists, and, generally, community members are satisfied with the work they perform (Prairie Research Associates, 2005). A Public Safety Canada review of the Band Constable Program in Manitoba concluded that these constables have a preventative effect on crime and divert a substantial number of criminal incidents away from the justice system (Lithopoulos, 2009). For First Nations without a nearby RCMP detachment, these officials are an indispensable part of a community's public safety.

While band constables still play an important role, there has been growing interest in the role of peacekeepers (who are also called community safety officers in some jurisdictions). Sunahara (2006) noted that peacekeepers use traditional methods such as restoration and reconciliation in their interactions with community members. While the range of duties carried out by peacemakers varies according to the First Nations involved, their crime prevention role is similar to that of the band constables, although they may be better trained and resourced, especially given that a number of community colleges in the prairie provinces are now offering certificate programs in peacemaking. Evidence gathered by Rigakos (2008) indicates that peacekeepers divert a substantial number of criminal incidents away from the justice system and have a preventative effect on youth-related crime (e.g., reducing acts of mischief or break and enter).

Much of the discussion so far has highlighted different forms or approaches to Aboriginal policing, including involving non-sworn officers. There has been a growing presence in civilian 
employees working in police agencies in both Canada and the United States. Burczycka (2011, 8 ), for instance, observed that there was one civilian employee for every 2.5 sworn officers in Canada on May 15, 2011, whereas the ratio in the United States was approximately two officers for each civilian employee in 2007 (Burch, 2012, p. 6). The roles and functions of these employees, however, vary considerably by agency, from those who support the agency (such as administrative and support staff) to community service officers who take crime reports - freeing sworn officers to engage in regular crime-fighting activities. Individuals who are providing a social control function, such as the band constables or peacekeepers, however, are more likely to be associated with Aboriginal policing.

Plural policing in Canada mirrors what is happening in other nations, where non-sworn community-based officials are taking a more active role in crime prevention (Rogers \& Gravelle, 2012). Barcham (2010), for instance, described the efforts of Maori wardens in supporting the police as well as their crime prevention efforts in New Zealand. Wood, Rosay, Postle, and TePas (2011) reported how village public safety officers, village police officers and tribal police officers support law enforcement, and sometimes act as the only type of formal social control in small and isolated Alaska villages. Willis $(2010,46)$, by contrast, described the roles of indigenous community liaison officers, Aboriginal community liaison officers, and police liaison officers in their support of community policing in Australia. While the roles and job descriptions of these officials differ in these three nations, the common element is to enhance informal social control and prevent crime while respecting the cultural needs of the community.

\section{(3) Researching the Life Course of Aboriginal Police Services}

It is important to understand how organizational development and change in police agencies influences service delivery. King (2009a) posited that police services have a life course and will pass through a series of events or turning points, including the agency's creation, founding, growth, decline, crisis, and disbanding. Each of these events shapes the organization, the activities of the employees, and relationships with agency stakeholders. This life course approach provides a framework for examining the disbandment and success of FNA police services.

As with any newly founded organization, there are growing pains that policing organizations must confront, and Aboriginal police services are no exception. Since the implementation of the FNPP, a total of seventeen self-administered police services have disbanded. That number is particularly high, considering that there were only 38 FNA agreements in 2010 and further research is needed to ascertain why these agencies failed. Barnsley (2002) noted that the incoming President of the First Nations Chiefs of Police Association told members that FNAs were "set up to fail" due to inadequate funding. In his report for the Ipperwash Inquiry, Linden (2007, p. 248) observed that Aboriginal police agencies were often small and lacked specialized policing services, but had high demands for services- 
including being tasked with policing large geographical areas - while lacking the legal or financial security of municipal agencies. Such comments and observations reinforce the fact that the FNA model of policing is still facing major on-going challenges and developmental pains.

King (2009b) suggests that police organizations are particularly vulnerable during their founding years to disbanding, and it is plausible that the failure of these FNA police services is consistent with what has occurred in other jurisdictions. Research in this area should analyze why Aboriginal police services failed and what are the factors for success for those services that have survived. As King (2009b: p. 1) noted, "Overall, police agencies disband because they cannot adapt to changes in their contingency and institutional environments or they change in inappropriate ways, and their small organizational size does not provide a sufficient buffer against external intrusion from the institutional environment." This research could contribute to the inventory of best practices and used as a road-map for the remaining FNA in their adaptation to current and future trends.

\section{Discussion and Conclusion}

Canada's First Nations Policing Program provides the funding and programmatic structure for policing 535 rural Aboriginal communities. After two decades and almost three billion dollars in expenditures, however, there has been comparatively little scholarly assessment of the strengths and weaknesses of this approach to rural policing. This commentary highlighted the current state of the Program, along with identifying key issues that will influence Aboriginal policing and Aboriginal policing research in the future. There are two key issues of concern: (1) the focus on the administrative-bureaucratic goals of the First Nations Policing Program and the relative inattention to program outcomes; and (2) the failure to develop a research based agenda and inventory of best practices in Aboriginal and rural policing. These shortcomings have limited the development of research, practice, policy, and theory, and ultimately, ensuring just and fair outcomes for Canada's Aboriginal and rural peoples.

Within this context, research efforts in Aboriginal policing have been undermined by the Canadian government's withdrawal of support for policy oriented policing research in the early 1990s. This has led to policy making and decisions based on intuitive and ideological judgements (which were sometimes proven to be wrong), rather than on deliberate reasoning based on research. Fortunately, this ad hoc approach to policy development and police governance was rejected by other national governments (e.g., Australia, United Kingdom, and United States). Moreover, evidence based policing research undertaken by academic scholars in other nations may have a stronger tradition than in Canada (see Murphy, 1999). Those policymakers and scholars recognized the value of empirical research in the development of evidenced-based policing policy and expanded government support for policy oriented policing research. 
To this end, there is a critical need to increase our knowledge of Aboriginal policing and how this aspect of law enforcement fits within the larger Canadian policing paradigm as well as rural policing. Research that responds to this gap in our knowledge should produce more information sharing, cooperation, and networking with police research experts both within and outside Canada, and between government and academia.

An Aboriginal policing research initiative is important from a policy perspective as the existence of effective and culturally appropriate policing provides a strong foundation for healthy, prosperous, and sustainable Aboriginal communities. Indeed, an often neglected aspect of socioeconomic development, both at the community and national levels, is the crucial role of effective policing in shaping economic expansion as well as reducing the economic and social burdens that victimization places on individuals, families, and communities. While most of the Aboriginal policing research to date has been completed by federal government investigators or by scholars under contract with the federal government, it is also important that academics participate in these studies as their perspectives can add to the discourse. 


\section{Endnotes}

${ }^{1}$ Aboriginal peoples, in this commentary, refers to North American Indians (with or without status), Métis (peoples of mixed ancestry), and Inuit peoples (peoples indigenous to Canada's north).

${ }^{2}$ Most policing research funded by the Canadian government is undertaken by private consulting firms and these reports are seldom published, therefore contributing little to the advancement of knowledge. For a critique of this practice, see Rigakos and Worth (2011, p. 648-651).

${ }^{3}$ Each First Nation or Band is allotted land reserved for their exclusive use and these are typically called reserves or reservations. There are 615 First Nations in Canada and while the average size is about 1,260 persons the actual number of persons living on these reserves is about half that number. Over one-third of these communities are located in isolated areas (e.g., accessible only by air, boat or roads for part of the year).

${ }^{4}$ The RCMP Indian Special Constable program was referred to as the RCMP 3(b) program and was later re-named as the RCMP Aboriginal Community Constable Program or ACCP. The program is cost-shared on a $46 \%$ federal $54 \%$ provincial basis.

${ }^{5}$ At its inception, the FNPP referred to the First Nations Policing Policy, but the FNPP is now called the First Nations Policing Program.

${ }^{6}$ FNPP did not define what "culturally appropriate" really means. The implication was that the majority of officers funded under the program would be Aboriginal.

${ }^{7}$ On-reserve communities include First Nation reserves, certain First Nations communities on Crown Lands and Inuit communities.

${ }^{8}$ This indicator included rating the performance of the local police service in: a) enforcing the laws; b) keeping citizens safe; c) responding quickly to calls for service; and d) supplying information to the public on ways to reduce crime. 


\section{References}

Adjin-Tettey, E. (2007). Sentencing Aboriginal offenders: Balancing offenders' needs, the interests of victims and society, and the decolonization of Aboriginal peoples. Canadian Journal of Women and the Law, 19, 179-216.

Alberta Government. 1991. Justice on Trial. Retrieved February 12, 2013, fromhttp://justice.alberta.ca/programs_services/aboriginal/Publications\%20Library\%2 0\%20Aboriginal\%20Justice/CawseyReportVolumeI.aspx/DispForm.aspx?ID=15

Alderson-Gill \& Associates. (2006). Royal Canadian Mounted Police Aboriginal Community constable program review. Ottawa, ON: Public Safety Canada.

Alderson-Gill \& Associates. (2008). Socio-demographic survey of police officers serving in Aboriginal communities. Ottawa, ON: Public Safety Canada.

Barcham, M. (2010). Indigenous community policing: Building strength from within. In J. Putt (ed.), Community policing in Australia (pp. 49-53). Canberra AUS: Australian Institute of Criminology.

Barnsley, P. (2002). Aboriginal policing - set up to fail? Windspeaker Magazine, 20, 13-15.

Bayley, D. H. \& Nixon, C. (2010). The Changing environment for policing, 1985-2008.

Retrieved Feb. 13, 2013 from:

http://www.hks.harvard.edu/var/ezp_site/storage/fckeditor/file/pdfs/centers-

programs/programs/criminal-justice/NPIP-The-Changing-Environment-for-Policing-19852008.pdf

Brzozowski, J., A. Taylor-Butts, \& Johnson, S. (2006). Victimization and offending among the Aboriginal population in Canada. Ottawa: Canadian Centre for Justice Statistics.

Burch, A.M. (2012). Sheriffs' offices 2007, statistical tables. Washington, DC: Bureau of Justice Statistics.

Burczycka, M. (2010). Police resources in Canada, 2010. Ottawa: Canadian Centre for Justice Statistics, Statistics Canada.

Burczycka, M. (2011). Police resources in Canada, 2011. Ottawa: Canadian Centre for Justice Statistics, Statistics Canada.

Cardinal, M. (1998). First Nations police services in Alberta review, Retrieved Feb. 12, 2013 from:http://justice.alberta.ca/publications/Pages/default.aspx 
Christmas, R. (2012). The people are the police: Building trust with Aboriginal communities in contemporary Canadian society. Canadian Public Administration, 55, 451-470.

Clairmont, D. 2006. Aboriginal policing in Canada: An overview of developments in First Nations. Retrieved Feb. 12, 2013 from: http://sociologyandsocialanthropology.dal.ca/Files/Aboriginal_Policing_in_Canada_Overvi ew_2006.pdf

Clairmont, D. (2009). Policing in Aboriginal communities: The evolution, successes and challenges. Retrieved Feb. 13, 2013, from: http://sociologyandsocialanthropology.dal.ca/Files/Ottawa_Police_Presentation__Clairmont_2009.pdf

Clairmont, D. \& Murphy, C. (2000). Self-Administered First Nations' Policing: An overview of organizational and managerial issues. Ottawa, ON: Solicitor General of Canada.

Dauvergne, M. (2012). Adult correctional services in Canada, 2010/2011. Ottawa, ON: Canadian Centre for Justice Statistics.

Department of Justice, Canada. (1985). Indian Act (R.S., 1985, c. I-). Retrieved Feb. 27, 2012, from http://laws-lois.justice.gc.ca/eng/acts/I-5/page-1.html\#s-2.

Department of Indian and Northern Development. (1982). An evaluation assessment of the Ontario Indian constable program. Ottawa: ON: Author.

Department of Indian and Northern Development. (1983). National evaluation overview of Indian Policing. Ottawa, ON: Author.

Department of Indian and Northern Development. (1990). Indian policing policy review. Ottawa, ON: Author.

Ekos Research Associates. (2005). First Nations syndicated study: First wave survey:Final report. Ottawa, ON: Author.

Goldstein, H. (1979). Improving policing: A problem-oriented approach. Crime \& Delinquency, $25,236-258$.

Hough, M. J. Jackson, B. Bradford, A. Myhill, \& Quinton, P. 2010. Procedural justice, trust, and institutional legitimacy. Policing: A Journal of Policy and Practice, 4, 203-210.

Jain, H. C., P. Singh, \& Agocs, C. (2000). Recruitment, selection and promotion of visibleminority and aboriginal police officers in selected Canadian police services. Canadian Public Administration, 43, 46-74. 
King, W. R. (2009a). Toward a life course perspective of police organizations. Journal of Research in Crime and Delinquency, 46, 213-244.

King, W. R. (2009b). Organizational failure and the disbanding of local police agencies. Crime \& Delinquency. Retrieved Feb. 12, 2013 from: http://cad.sagepub.com/content/early/2009/09/08/0011128709344675.full.pdf+html

LeBeuf, M. (2011). The role of the Royal Canadian Mounted Police during the Indian residential school system. Ottawa, ON: Royal Canadian Mounted Police.

Linden, S. B. (2007). Report of the Ipperwash inquiry. Toronto, ON: Government of Ontario.

Lithopoulos, S. (1986). The making and maintaining of the RCMP's image: An analysis of the development of a national symbol. Ottawa, ON: University of Ottawa.

Lithopoulos, S. (2007). International comparison of Indigenous policing models. Ottawa, ON: Public Safety Canada.

Lithopoulos, S. (2009). Aboriginal sovereignty and the resurgence of bottom-up policing in Canada. Ottawa, ON: (Unpublished paper).

Lithopoulos, S. \& Ruddell, R. (2011). Policing isolated Aboriginal communities: perspectives of Canadian officers. Policing: An International Journal of Police Strategies \& Management, $34,434-453$.

Loader, I. (2000). Plural policing and democratic governance. Social \& Legal Studies, 9, 323345.

Lum, C., C. S. Koper, \& Telep, C.W. (2011). The evidence-based policing matrix. Journal of Experimental Criminology, 7, 3-26.

Merritt, J. \& Dingwall, G. (2010). Does plural suit rural? Reflections on quasi-policing in the countryside. International Journal of Police Science \& Management, 12, 388-400.

Murphy, C. (1999). Current and future state of police research and policy in Canada. Canadian Journal of Criminology, 41, 205-215.

Murphy, C. \& Clairmont, D. (1996). First Nations police officerssSurvey. Ottawa, ON: Solicitor General Canada.

National Research Council. (2004). Fairness and effectiveness in policing: The evidence. Washington D.C.: National Academies Press. 
Navigant Consulting. (2008). Report on the Forensic Audit of Funding Under Contribution Agreements with the Mohawk Council of Kanesatake during the period April 1, 2003 to March 31, 2005. Toronto: Author.

Nettelbeck, A. \& Smandych, R. (2010). Policing indigenous peoples on two colonial frontiers: Australia's mounted police and Canada's northwest mounted police. The Australian and New Zealand Journal of Criminology, 43, 356-375.

Office of the Auditor General of Canada. (2005). Chapter 1 - Royal Canadian Mounted Police Contract Policing, in 2005 Report of the Auditor General of Canada. Retrieved August 18, 2009, from http://www.oag- bvg.gc.ca/internet/ English/parl_oag_200511_01_e_14939.html.

Perreault, S. \& Brennan, S. (2010). Criminal victimization in Canada, 2009. Ottawa, ON: Statistics Canada.

Prairie Research Associates. (2005). Evaluation of the Indian band constable program: Final report. Winnipeg, MB: Author.

Prairie Research Associates. (2006). Evaluation of the First Nations policing program: Final report, Volume I. Winnipeg, MB: Author.

Public Safety Canada. (2009). First Nations policing program, Retrieved Feb. 12, 2013 from: http://www.publicsafety.gc.ca/prg/le/ap/1index-eng.aspx

Public Safety Canada. (2010a). 2009-2010 Evaluation of the First Nations policing program. Ottawa: Author.

Public Safety Canada. (2010b). Comprehensive review of the First Nations policing program. Ottawa, ON: Author.

Rigakos, G. (2008). Plural policing study in Saskatchewan First Nations. Ottawa, ON: Public Safety Canada.

Rigakos, G. \& Worth, S. R. (2011). Access to information (ATI) as a double-edged sword for critical policing research. Canadian Journal of Law and Society, 26, 645-652.

Robertson, N. (2012). Policing: Fundamental principles in a Canadian context. Canadian Public Administration, 55, 343-363.

Rogers, C. \& Gravelle, J. (2012). UK policing and change: Reflections for policing worldwide. Review of European Studies, 4, 42-51. 
Ruddell, R. \& Lithopoulos, S. (2011). Officer perceptions of Canada's First Nations policing program. The Police Journal, 84, 151-170.

Sherman, L. W. (1998). Evidence-based policing. Washington, DC: Police Foundation.

Sherman, L. W. (2011). Democratic policing on the evidence. In J. Q. Wilson \& J Petersilia (eds.), Crime and public policy (pp. 589-618). New York: Oxford University Press.

Smith Associates et. al. (1997). Evaluation of the Ontario First Nations policing arrangement. Ottawa, ON: Solicitor General of Canada.

Solicitor General of Canada. (1992a). First Nations policing policy. Ottawa, ON: Author.

Solicitor General of Canada. (1992b). Report for the Royal Commission on Aboriginal Peoples. Ottawa, ON: Author

Solicitor General of Canada. (1996). First Nations policing policy. Ottawa, ON: Author

Statistics Canada. (2008). Aboriginal Peoples in Canada in 2006: Inuit, Métis and First Nations, 2006 Census. Ottawa, ON: Author.

Sunahara, D. F. (2006). Peace officer and peacekeeper: An examination of training needs. Ottawa, ON: Canadian Police College.

Tyler, T. R. (2006). Why people obey the law. Princeton NJ: Princeton University Press.

Unnever, J. D. \& Gabbidon, S. L. (2011). A theory of African American offending: Race, racism, and crime. New York: Routledge.

Willis, M. (2010). Aboriginal liaison officers in community policing. In J. Putt (ed.) Community policing in Australia (pp. 41-48). Canberra AUS: Australian Institute of Criminology.

Wood, D. S., Rosay, A., Postle, G. \& Tepas, K. (2011). Police presence, isolation, and sexual assault prosecution. Criminal Justice Policy Review, 22, 330-349. 
Appendix A: First Nations Policing Program: Number of Tripartite Policing Agreements and Expenditures, 1992 to 2012 (Canadian Dollars)

\begin{tabular}{|c|c|c|c|c|c|}
\hline Year & $\begin{array}{l}\text { Number of } \\
\text { Agreements }\end{array}$ & $\begin{array}{c}\text { Federal } \\
\text { Expenditures }\end{array}$ & $\begin{array}{c}\text { Estimated } \\
\text { Provincial } \\
\text { Expenditures }\end{array}$ & $\begin{array}{c}\text { Total } \\
\text { Expenditures }\end{array}$ & $\begin{array}{l}\text { Percent } \\
\text { Increase }\end{array}$ \\
\hline 1992 & 1 & $18,600,000$ & $8,715,253$ & $27,315,253$ & $0 \%$ \\
\hline 1993 & 7 & $28,000,000$ & $17,786,232$ & $45,786,232$ & $51 \%$ \\
\hline 1994 & 18 & $32,000,000$ & $20,681,665$ & $52,681,664$ & $14 \%$ \\
\hline 1995 & 47 & $39,449,000$ & $26,859,305$ & $66,308,304$ & $23 \%$ \\
\hline 1996 & 72 & $49,400,000$ & $35,812,406$ & $85,212,406$ & $25 \%$ \\
\hline 1997 & 100 & $50,100,000$ & $36,174,148$ & $86,274,147$ & $1 \%$ \\
\hline 1998 & 108 & $51,400,000$ & $37,292,936$ & $88,692,935$ & $3 \%$ \\
\hline 1999 & 115 & $55,800,000$ & $40,981,248$ & $96,781,248$ & $9 \%$ \\
\hline 2000 & 123 & $58,100,000$ & $42,688,800$ & $100,788,800$ & $4 \%$ \\
\hline 2001 & 123 & $59,547,800$ & $43,560,000$ & $103,107,800$ & $2 \%$ \\
\hline 2002 & 123 & $65,250,000$ & $48,400,000$ & $113,650,000$ & $10 \%$ \\
\hline 2003 & 127 & $73,000,000$ & $55,000,000$ & $128,000,000$ & $11 \%$ \\
\hline 2004 & 128 & $79,583,500$ & $71,000,000$ & $150,583,500$ & $10 \%$ \\
\hline 2005 & 132 & $85,554,000$ & $76,326,550$ & $161,880,550$ & $8 \%$ \\
\hline 2006 & 150 & $90,952,000$ & $81,142,347$ & $172,094,347$ & $6 \%$ \\
\hline 2007 & 164 & $98,200,000$ & $87,608,612$ & $185,808,612$ & $8 \%$ \\
\hline 2008 & 165 & $104,000,000$ & $92,783,052$ & $196,783,051$ & $6 \%$ \\
\hline 2009 & 167 & $112,950,657$ & $100,768,333$ & $213,718,990$ & $7 \%$ \\
\hline 2010 & 167 & $111,876,448$ & $99,809,983$ & $211,686,431$ & $7 \%$ \\
\hline 2011 & 168 & $119,881,911$ & $106,952,015$ & $226,833,926$ & $7 \%$ \\
\hline 2012 & 163 & $122,434,959$ & $109,229,703$ & $231,664,662$ & $7 \%$ \\
\hline Total & ----- & $1,506,080,275$ & $1,239,572,588$ & $2,745,652,858$ & ------ \\
\hline
\end{tabular}

Source: Departmental Performance Reports: Solicitor General Canada (1992-2002) and Public Safety Canada (2003-2012 unpublished data). 